SUBRAMANIAN RANGAN

Harvard University

ROBERT Z. LAWRENCE

Harvard University

\title{
The Responses of U.S. Firms to Exchange Rate Fluctuations: Piercing the Corporate Veil
}

IN THE MID-1980s, when the dollar declined from its record highs, observers impatiently waited for the U.S. trade balance to respond. In the short run, instead of improving, the deficit continued to erode. Among economists, this sparked considerable research of both an empirical and theoretical nature. The empirical research appeared to uncover important differences in the behavior of U.S. and foreign firms that helped explain the sluggish response of the U.S. trade balance. U.S. exporters, it appeared, fixed their export prices in dollar terms and fully passed the exchange rate effects through into their foreign currency prices; indeed, as figure 1 shows, between 1985 and 1989 the U.S. export price index compiled by the Bureau of Labor Statistics (BLS) moved precisely in line with the domestic wholesale price index. ${ }^{1}$ As Paul R. Krugman and Richard E. Baldwin observe, this implied that measured in dollars, any

This paper reflects work in progress on a Brookings research project on U.S. corporate responses to the dollar funded by the Sloan Foundation, and on Subi Rangan's Ph.D. dissertation. We are grateful to Mun Ho, Mike Scherer, and Raymond Vernon for extremely helpful comments.

1. While this statement holds on average, some studies using disaggregated data indicate that in some industries, U.S. firms do not fully pass exchange rate changes through into export prices. For example, see Hooper and Mann (1989), Marston (1991), and Knetter (1993). 
Figure 1. U.S. Export Prices and Domestic Prices, 1980-90

Index, $1980=100$

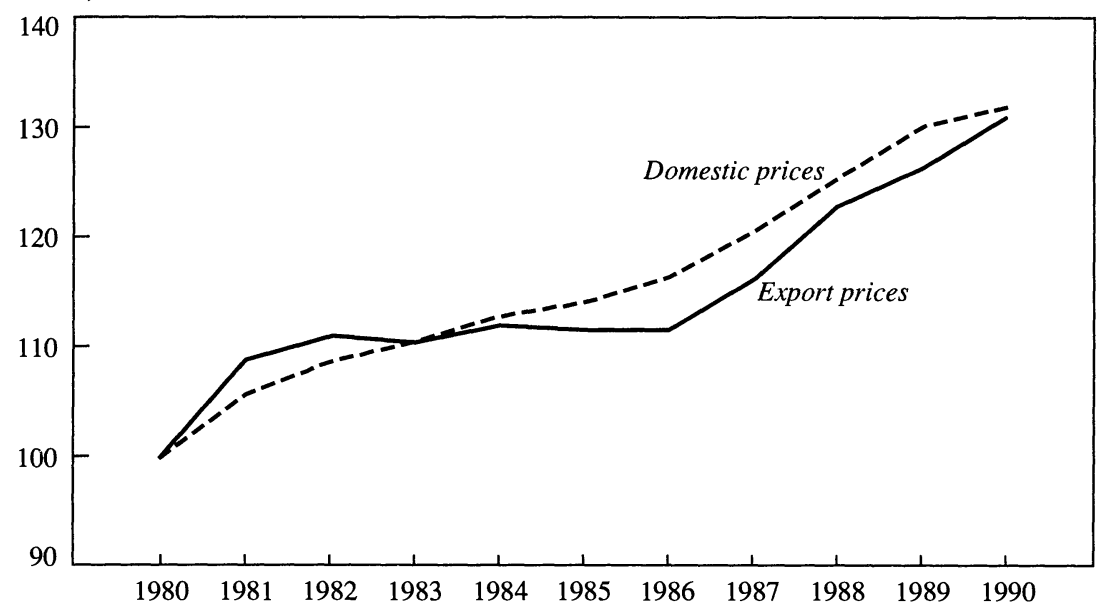

Source: Lawrence (1990a, table 5, p. 354).

a. Prices were constructed by the authors and exclude agricultural and computer products. For details of how these indexes were constructed, see Lawrence (1990a, pp. 351-53).

rise in U.S. export values rested heavily on the demand responses of foreign buyers-a response that history suggested could take time. ${ }^{2}$

Foreign producers selling in the United States, however, appeared to behave differently. In particular, Japanese and German firms competing in U.S. markets stabilized their dollar prices and allowed their profit margins to shrink in an attempt to maintain U.S. market share. While this behavior helped dampen the $J$-curve effect that comes from higher import prices, some economists argued that it stifled the adjustment process. $^{3}$

The passage of time and subsequent research demonstrated that these misgivings about the trade adjustment process were misplaced. ${ }^{4}$ The response of trade flows to the dollar was both substantial and predictable on the basis of traditional econometric specifications, but it took far longer than many observers had anticipated.

Nonetheless, the debate about U.S. adjustment stimulated some important theoretical research. A basic theoretical model would predict

2. Krugman and Baldwin (1987).

3. See Hooper and Mann (1989) and Krugman and Baldwin (1987).

4. See Lawrence (1990a) and Krugman (1991). 
full pass-through when firms price by applying constant markups over marginal cost. However, the phenomenon of incomplete pass-through, due to "pricing to market," also received considerable attention. ${ }^{5}$ Pricing to market refers to the behavior of exporters, who, in an attempt to maintain their foreign currency prices at an optimal level, absorb at least some portion of changes in the exchange rate in their profit margins. In general, they will take rising profit margins on their foreign sales when the exchange rate depreciates and falling profit margins when the exchange rate appreciates. ${ }^{6}$ Importantly, changes in the foreign market prices of these firms will deviate from changes in their home country prices in a direction that is consistent with being sensitive to local market conditions and the prices offered by competitors. ${ }^{7}$

Recent research has suggested several reasons why firms might not fully pass through exchange rate changes into prices if they had market power. Kenneth A. Froot, Paul D. Klemperer, and Kenneth Kasa focused on the role of market share and demand dynamics; Avinash K. Dixit and Richard Baldwin highlighted the importance of sunk costs, supply side dynamics, and hysteresis; Rudiger Dornbusch, Peter Hooper, Catherine L. Mann, Michael M. Knetter, and Paul R. Krugman emphasized the long-term value-maximizing strategic behavior of firms in oligopolistic markets; and Richard C. Marston focused on the defensive responses of firms to temporary "misalignments" of exchange rates. ${ }^{8}$

But the very plausibility of these theoretical demonstrations of the optimality of pricing-to-market behavior shifted the nature of the puzzle and raised an important question. Why was the behavior of U.S. firms apparently so different from that of their foreign counterparts? These theories suggested that firms competing in oligopolistic markets-where market shares matter and reentry (sunk) costs are high-would tend to cushion local currency prices from fully reflecting changes in the exchange rate, at least in the short run. Yet, even though U.S. manufactured exports are heavily concentrated in precisely those product areas

5. Krugman (1987).

6. Feenstra (1989, p. 29).

7. Marston (1991).

8. Froot and Klemperer (1989) and Kasa (1992); Dixit (1989) and Baldwin (1988); Dornbusch (1987), Hooper and Mann (1989), Knetter (1989), and Krugman (1987); and Marston (1991). 
in which oligopolistic pricing practices ought to dominate, U.S. exporters appeared to pass exchange rate changes through into their export prices in an almost mechanical fashion.

What could explain the observed pricing behavior of U.S. firms? In the export pricing literature, four lines of explanation have been advanced for their apparently unique pass-through behavior.

MYOPIA. The first is that managers of U.S. firms are inward-looking and simply do not care about foreign sales; their pricing behavior reflects a "take it or leave it" attitude. But this view is hard to reconcile with the major interest U.S. firms have displayed in foreign markets, as shown in their direct foreign investment behavior. An alternative reason given for myopia is that U.S. firms have high discount rates and are thus unwilling to see their profit margins erode. ${ }^{9}$ But this view could not explain why U.S. firms did not raise their profit margins when the dollar declined.

MENU COSTS. A second view maintains that U.S. firms do not pricediscriminate across markets because such policies are too costly to administer. After all, exports account for only a small portion of overall sales. ${ }^{10}$ For example, the Fortune list of the fifty largest U.S. exporters in 1990 showed only eleven firms for whom exports exceeded 20 percent of sales. ${ }^{11}$ But the menu cost explanation also appears to be implausible. Firms should behave optimally on all their sales. The relevant issue is not whether exports are small compared to domestic sales, but whether they are sufficiently large to justify the additional cost of administering strategic pricing policies. Because U.S. exports of manufactured goods are concentrated among a few large firms and-in the aggregate-actually exceed those of Japan in dollar value, this argument surely does not stand up to scrutiny.

ARBITRAGE. A third explanation rests on the recognition that pricing to market implies a divergence in changes in a firm's prices internationally, and thus an ability to segment markets without fear of arbitrage. Proponents of this explanation argue that U.S. firms face a higher degree of pressure from arbitrageurs than do their Japanese or German counterparts and are therefore less able-or perhaps even unable-to price-

9. Ohno (1990).

10. See Hooper and Mann (1989); Knetter (1989); and Lawrence (1990b).

11. James Beeler, “Exports: Ship 'Em Out," Fortune, Spring/Summer, 1991, Special Issue, p. 59. 
discriminate across markets. ${ }^{12}$ But arbitrage possibilities should surely run in both directions. If the United States is so open that Americans cannot price-discriminate abroad-so that price deviations between, for example, the United States and Germany for U.S. products will be arbitraged away-why does the process not work in reverse for German goods sold in the United States?

DATA PROBlems. A fourth explanation is that the price data on which these findings are based are themselves questionable. ${ }^{13}$ This explanation raises the possibility that U.S. firms did price to market, even though the official data suggested that exchange rate movements were largely passed through to prices. Domestic and export prices are collected by the BLS through similar mail surveys. Indeed, in many responding companies, the same department is responsible for answering both surveys. In an early study of export price behavior, Irving B. Kravis and Robert E. Lipsey found that firms were reluctant to provide different export and domestic prices for the same products, apparently in fear of accusations of price discrimination. ${ }^{14}$ While other researchers have ignored this argument, we believe it should be taken more seriously than it has. ${ }^{15}$

To sort through alternative explanations, we decided to violate the norms of our profession by actually asking firms what they do. We appended a set of questions on pricing behavior to a survey of the exchange rate responses of twenty-five major U.S. companies conducted by Donald R. Lessard and Srilata A. Zaheer of the Massachusetts Institute of Technology. ${ }^{16}$ In addition, we conducted detailed interviews with senior executives responsible for pricing in three major U.S. exporting firms. The responses we obtained indicated behavior that was more like the pricing-to-market behavior that one might expect in theory than the complete pass-through behavior reflected in the BLS export price index. Specifically, the survey concentrated on respondents' behavior in the

12. See Marston (1991).

13. See Lipsey, Molinari, and Kravis (1991) and Lipsey (1993).

14. Kravis and Lipsey (1971).

15. In fact, the BLS export price index, which is based on the unweighted responses of more than 2,000 firms, probably gives a disproportionate weight to small firms that are subject to "menu costs" and likely to charge their foreign buyers their U.S. dollar prices.

16. Lessard and Zaheer's unpublished survey entitled "Corporate Responses to Volatile Exchange Rates" was conducted in late 1989 and early 1990. 
face of the major 40 percent effective real depreciation of the dollar from 1985 to 1989. Eighty percent of the firms surveyed said that their pricing decisions were made in the local market. Depending on the geographic region in which the firm operated, between half and two-thirds of the firms indicated that they had "kept local currency prices constant" in the face of the precipitous decline of the dollar between 1985 and 1989. ${ }^{17}$

How can one reconcile the empirical findings that exchange rates are almost fully passed through into export prices with both theoretical considerations that U.S. firms should price to market and survey and case study evidence that they do price to market? The key to resolving this apparent contradiction lies in the last explanation offered above: data problems. In particular, in an important number of cases, official U.S. export prices do not actually indicate the prices paid by final purchasers of U.S. products abroad. In our view, for a significant proportion of U.S. exports-particularly those that take the form of intrafirm tradeexport price changes are more likely to reflect changes in the internal prices at which products are transferred between headquarters and their affiliates. Moreover, we believe that export prices will reflect transfer prices, not only for most of the approximately 40 percent of manufactured exports that are shipped overseas intrafirm, but also-because of sampling practices-for a significant fraction of the 40 percent of manufactured exports that are exported at arms length by U.S. multinationals.

In this paper, we will examine the pricing and sourcing behavior of U.S. multinationals in response to the exchange rate changes in the 1980s, with emphasis on the post-1985 period of dollar depreciation. We will first present evidence that supports our two-stage interpretation of the pricing practices of these firms. We will then show that, as theory would predict, U.S. multinationals located abroad do not fully pass through exchange rate changes into their final product prices, and that they alter their profit margins in a manner consistent with pricing-tomarket behavior. On the basis of this finding, we conclude that studies

17. Anecdotal evidence also suggests that U.S. firms do not pass through exchange rate changes in the way the export price data suggest. See for example, Ferdinand Protzman, "Why Lower Dollar Didn't Work," New York Times, December 1, 1992, p. D1, which argues that "U.S. exports didn't get cheaper and imports dearer." See also Andrew Pollack, "In Yen Windfall, U.S. Companies Prefer Profits," New York Times, May 5, 1993, p. D1. 
that have relied solely on BLS export prices or unit values as proxies for final purchase prices have been misled. We will also present evidence suggesting that the sourcing decisions of U.S. multinationals are responsive to changes in relative costs. Indeed, in response to the dollar's decline after 1985, intrafirm exports responded by as much as arms-length exports in the same industry. Because export prices (and wholesale prices) provide reasonable proxies for these relative costs, economists who have used these series in explaining trade flows have actually been (almost) right, albeit for the wrong reasons.

\section{The BLS Export Price Index and Intrafirm Trade}

In principle, it would not be surprising to see that, in a multinational corporation, exports will be priced differently for internal distribution and external sales purposes. Theory suggests, for example, that a discriminating monopolist will set prices to differentiate the markup over marginal cost according to demand conditions in different market segments. On the other hand, theory also indicates that if a firm can source its product from a variety of locations, it should ensure that the marginal cost of sourcing from each location is equalized. These theoretical considerations suggest that both pricing and sourcing decisions will be based on measures of marginal cost, but that internal and external prices of exports may differ.

Firms could implement their strategies on a centralized or decentralized basis. In principle, corporate headquarters could dictate all pricing and sourcing decisions. Alternatively, the firm could rely on a decentralized internal market in which intermediate products are made available to various subsidiaries at a price that reflects marginal costs. The subsidiaries could then make independent pricing decisions in their sales (to final purchasers), as well as independent sourcing decisions. Both the centralized and decentralized approach should lead to the same outcome, and it is likely that firms using each strategy can be found.

Does the BLS export price index capture external or internal prices? The BLS believes its index reflects the external price. BLS official William Alterman describes the export price index as representing "what has happened to the price of U.S. exports and imports from the stand- 
point of the average foreign buyer or seller." ${ }^{18}$ Further, the literature testing U.S. pricing-to-market behavior typically assumes this to be the case. However, we disagree, particularly when it comes to intrafirm exports.

Consider figure 2, which plots changes between 1985 and 1989 in the ratio of U.S. export prices to producer prices for a number of manufacturing industries against the share of U.S. multinational exports accounted for by intrafirm trade. A striking relationship emerges. The higher the share accounted for by intrafirm trade, the more closely export price changes match domestic price changes. If the BLS were really capturing prices to final purchasers, this relationship would not be expected. Indeed, intrafirm trade is concentrated in the more oligopolistic sectors, where pricing-to-market practices could be expected to dominate. The figure also indicates that in industries in which a higher share of U.S. multinational exports are sold at arm's length, prices tend to reflect local market conditions; measured in U.S. dollars, relative export prices rose in response to the exchange rate. In contrast, almost no change is apparent in the relative export prices of goods sold in industries with larger shares of intrafirm trade; their prices apparently moved in line with domestic producer prices.

There are four reasons why we think export prices and domestic prices move together in industries with a high share of multinational intrafirm trade:

EFFICIENCY. If pricing decisions are decentralized, the export price that is likely to be used by the U.S. firm will be a cost-plus version that serves as a marginal cost proxy for firm allocation decisions. ${ }^{19}$

TAX REGULATION. When transfer pricing practices are monitored, the price at which arm's-length sales are made in the United States generally is the measure most acceptable to the tax authorities in source and destination nations.

administrative Convenience. Because the pricing report to the BLS comes from the U.S. parent, it will be easier to report the domestic wholesale price than the price actually paid by the foreign buyer, particularly if the foreign subsidiary has some pricing authority. Moreover,

18. Alterman (1991, p. 128).

19. See Hirshleifer (1956); Eden (1985); Diewert (1985); and Benke and Edwards (1980, appendix B). 
Figure 2. Change in Real U.S. Export Prices and Share of Intrafirm Trade for Manufacturing Industries

Percent change in real U.S. dollar export prices, 1985-89

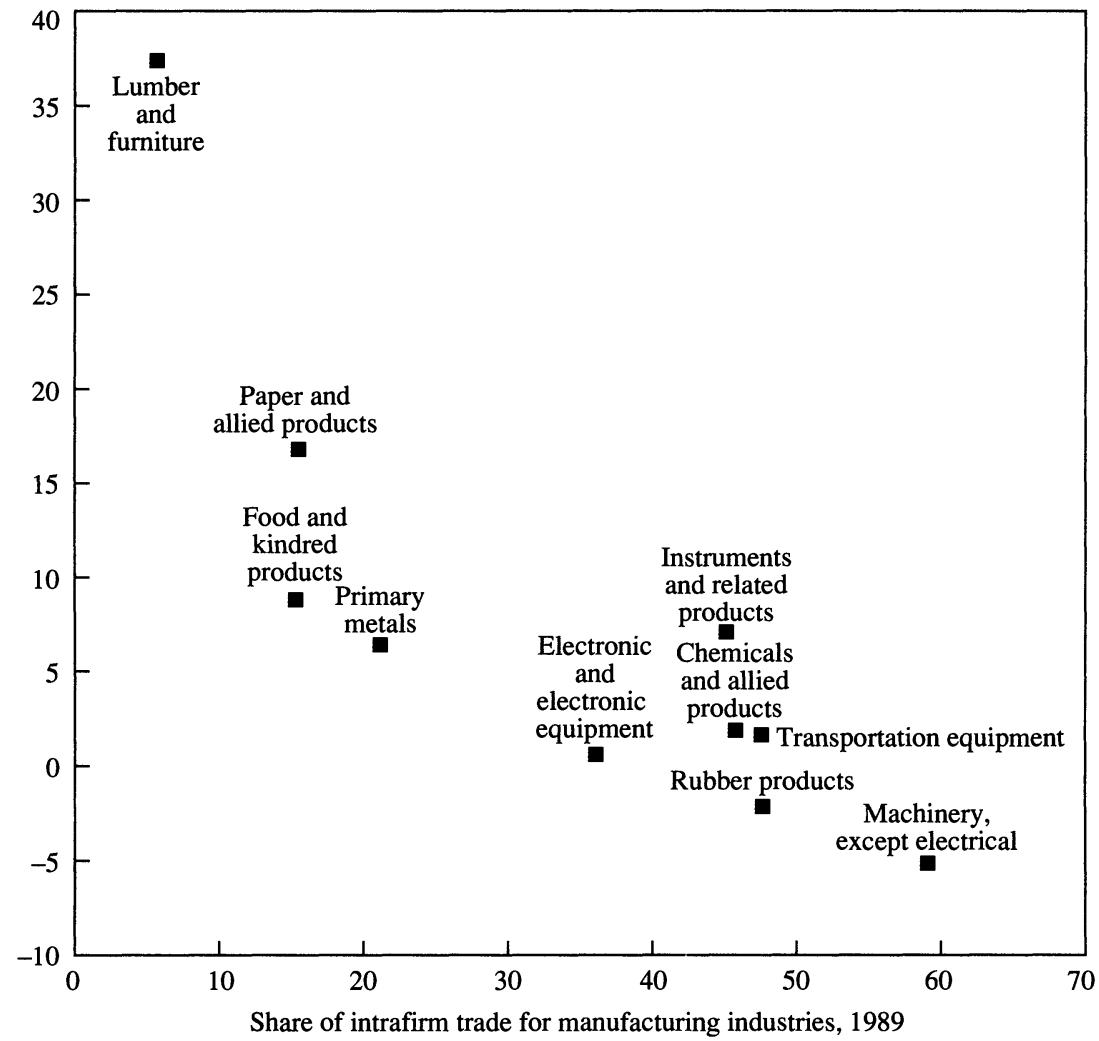

Source: Intrafirm share data are from U.S. Bureau of Economic Analysis (1991, Preliminary Results, table 85, columns 6 and 14) and U.S. Bureau of Economic Analysis (1991, table 57, columns 1 and 4). Producer prices are from U.S. Bureau of Labor Statistics, Monthly Labor Review (January 1991, table 36, p. 108). Export prices are from an unpublished series from the U.S. Bureau of Labor Statistics entitled “U.S. Dollar Export Price Index, Average Exchange Rates, and Foreign Currency Price Indexes-nominal (1985=100). '

a. U.S. export prices are deflated using sectoral producer price indexes.

BLS policy dictates that "if it is determined that the buyer and the seller are affiliated and that the transaction price for the product does not mirror market trends," then the price data will not be collected. ${ }^{20}$ However, the market trends that are readily available to the person filling out the BLS report in the United States are more likely to be the U.S. wholesale

20. Alterman (1991, p. 137). Emphasis added. 
or list prices than the prices paid by the unaffiliated foreign buyer to the affiliated seller in a foreign country. ${ }^{21}$

TARIFFS. In the face of a currency depreciation, firms have an incentive to save on ad valorem taxes and use the lower foreign equivalent of the U.S. price rather than the higher foreign transaction price. (Of course, in the case of an appreciation, they would prefer the foreign price. $)^{22}$

The first two of these explanations, efficiency and tax regulation, apply particularly to the intrafirm trade of multinationals, while the other two considerations, administrative convenience and duties, apply to all exports. Figure 2 suggests that the first two explanations are more important; changes in the price measures reported to the BLS by firms with a substantial share of intrafirm trade are more likely to reflect changes in the marginal cost of sourcing in the United States than the prices paid by the average foreign buyer. Moreover, once firms are reporting such prices as representative of their intrafirm trade, they are unlikely to report a different price for their trade in the same products that are sold to other locations at arm's length.

If we are correct, does this mean that the export price data are wrong? Not necessarily. In fact, both the internal and external prices are relevant to the firms' adjustment process. Given constant marginal costs, the external price is relevant for adjustments along the demand curves of final purchasers; the internal price is relevant for adjustments along the derived demand curve for exported inputs used in affiliate sourcing. Therefore, the full adjustment to an exchange rate change by a multinational company will reflect both types of movements. Moreover, if firms do report changes in their domestic wholesale price, they are likely to be giving a fairly accurate picture of changes in their marginal costs. As a first approximation, if the product contains no imported inputs and marginal cost is constant, the dollar marginal cost of a product will not change in response to the exchange rate. If, however, marginal costs do change, either because of changes in input prices or changes in quantities produced where supply is not infinitely elastic, changes in the marginal cost will resemble those of changes in the domestic price. Indeed, if the domestic price is a constant markup over marginal costs, changes

21. See Lipsey (1993).

22. See Horst (1971) and Feenstra (1989). 
in domestic prices will give an accurate picture of changes in marginal cost, even though the levels will differ. Accordingly, changes in the domestic wholesale price will generally be a useful proxy for changes in the marginal cost relevant for intrafirm sourcing decisions.

\section{U.S. Trade and Multinational Activity}

In the United States, exporting of manufactured products is heavily concentrated in a relatively small number of large, multinational firms. In 1990, America's top fifty exporters, all multinationals, accounted for roughly 40 percent of U.S. manufacturing exports. ${ }^{23}$ For the same year, the Compustat database indicates that while large manufacturing firms (those with sales exceeding $\$ 500$ million) accounted for only 20 percent of the more than 1,000 U.S. exporters in the database, these large firms accounted for 93.2 percent of the total exports of all reporting firms. ${ }^{24}$ Similarly, Commerce Department data indicate that the U.S. parents of multinational enterprises accounted for 82 percent of U.S. manufacturing exports in $1989 .{ }^{25}$ Breaking down the export data in another dimension, intrafirm trade accounted for 38.6 percent of U.S. manufactured exports in 1989. ${ }^{26}$ As figure 3 shows, if aircraft exports (almost all of which are made at arm's length) are excluded, then the intrafirm share in U.S. manufactured exports jumps to 43.3 percent. More than three-quarters of these intrafirm exports were by U.S. parents to their majority-owned foreign affiliates, with the balance going between U.S. affiliates and their foreign parents. In general, U.S. multinationals ship about half their exports intrafirm to their own affiliates abroad. ${ }^{27}$

23. James Beeler, "Exports: Ship 'Em Out," Fortune, Spring/Summer 1991, Special Issue, p. 59; U.S. Bureau of Census and U.S. Bureau of Labor Statistics (1992, table 5).

24. Standard and Poors, Compustat database, February 1992.

25. U.S. Bureau of Economic Analysis (1991, Preliminary Results, table 85, column 1) and U.S. Bureau of Census and U.S. Bureau of Labor Statistics (1992, table 5).

26. See Rangan (forthcoming). As Catherine Mann pointed out to us, for purposes of evaluating the foreign-market pricing responses of U.S. firms, even this number may be an underestimate. She notes that an increasing proportion of U.S. exports will make a roundtrip to the United States because they are sent abroad by U.S. firms to foreign enterprises that assemble or add value to the exported products and then ship them back to the U.S. firm. In such instances, Mann notes, the U.S. firm has little incentive to price such "exports" strategically.

27. U.S. Bureau of Economic Analysis (1991, Preliminary Results, table 85, columns 14 and 15, which exclude "other transportation"). 
Figure 3. Intrafirm Manufacturing Exports of U.S. Multinationals, 1989

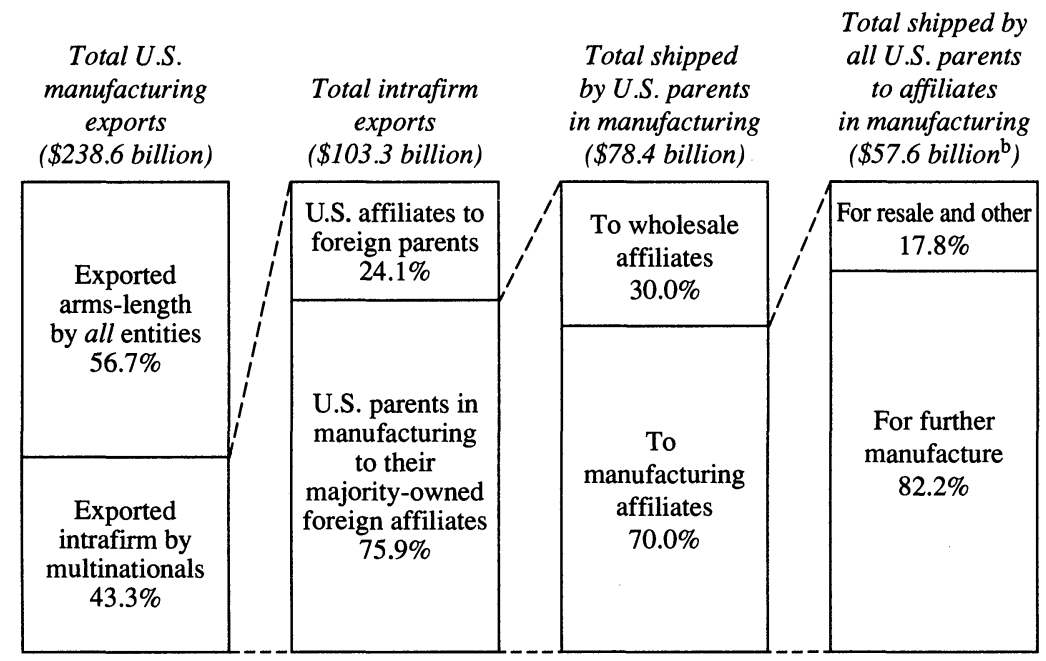

Source: U.S. manufacturing export data are from U.S. Bureau of Census and U.S. Bureau of Labor Statistics (1992, table 5). Intrafirm data are from U.S. Bureau of Economic Analysis (1991, table 85, column 6; table 71, columns 6-9) and U.S. Bureau of Economic Analysis (1991), table G-1, columns 1, 2, and 4).

a. Excludes aircraft.

b. This number includes exports shipped by nonmanufacturing parents to manufacturing affiliates and is hence larger than implied in the box to the left.

Although multinationals loom large in U.S. exports, exports do not play a large role in the overall foreign sales of U.S. multinationals. In 1989 , arm's-length exports accounted for only 22 percent of the total sales that U.S. multinationals in manufacturing made to unaffiliated foreign customers. ${ }^{28}$ This indicates that it is not exports but foreign affiliate production and sales that are the central channel through which U.S. firms reach their foreign customers and compete internationally. Furthermore, for products that are made and sold by the foreign manufacturing affiliates of U.S. parents, the level of U.S. content (that is, inputs sourced in the United States) is quite low, averaging around 20 percent. ${ }^{29}$

For our purposes, these data demonstrate two key points. First, analysts investigating U.S. export behavior ignore, at their peril, the role

28. U.S. Bureau of Economic Analysis (1991, Preliminary Results, table 85, columns 5 and 13 ; table 41 , column 9).

29. Authors' estimates from U.S. Bureau of Economic Analysis (1988, table 28, column 7; table 52, column 3). 
of multinationals in general and intrafirm exports in particular. Second, discussions about the behavior of "U.S. firms" should be clear on whether they refer to U.S.-based firms or U.S.-owned firms. A significant share of U.S. exports is ultimately priced and sold not by firms located in the United States but by their foreign affiliates. U.S. export prices, therefore, may not be the most appropriate data to answer the question of whether the goods sold abroad by U.S.-owned firms to final purchasers are priced to market. To answer this question, we must move beyond an examination of U.S. export prices to a "direct" examination of the second-stage external prices that arm's-length foreign customers are charged by U.S. firms' foreign affiliates. We do this in the next section.

\section{Do U.S. Multinationals Price to Market?}

U.S. multinationals are concentrated in oligopolistic, high-technology industries, including chemicals, machinery, and scientific instruments. In these industries, U.S. firms have considerable market power, arising both from their technological superiority and their large size. Under such circumstances, standard price theory for monopolists indicates that firms will set their prices so that the markup they charge over marginal cost will be inversely related to the price elasticity of demand they face.$^{30}$ If this elasticity is constant, the markup will remain constant, and prices and marginal costs will change proportionately.

For ease of exposition, consider the case of a U.S. multinational that is a monopolist in its market abroad. Assume that it faces an inverse demand function, $P=f(Q)$, and a cost function, $C(Q) e+C^{*}(Q)$, where $P$ is the price in foreign currency terms, $Q$ is the quantity sold abroad, $C$ is the cost incurred in the United States (in dollars), $e$ is the nominal exchange rate defined as foreign currency units per U.S. dollar, and $C^{*}$ is the cost in foreign currency terms incurred in the foreign country. The firm will set prices so as to maximize its profits, which can be written as

$$
\pi=P(Q) Q-C(Q) e-C^{*}(Q) .
$$

The standard first-order condition for this firm can be written as

$$
P=[\eta /(\eta+1)]\left[C^{\prime} e+C^{* \prime}\right],
$$

30. See Waterson (1984), especially chapter 2. 
where $\eta$ is the price elasticity, and the cost terms represent the marginal cost incurred in the U.S. and abroad respectively in foreign currency terms. If the marginal costs facing the monopolist are constant (that is, $\left.C^{\prime \prime}, C^{* \prime \prime}=0\right)$,

$$
\Delta P=\Delta \lambda\left(C^{\prime} e+C^{* \prime}\right)+\lambda C^{\prime} \Delta e,
$$

where $\lambda$ is the monopolist's markup over marginal costs and is equal to $\eta /(\eta+1)$.

From equation 2, the firm's price-cost margin, $P C M=\left[P-\left(C^{\prime} e+\right.\right.$ $\left.\left.C^{* \prime}\right)\right] / P$, can be expressed as

$$
P C M=1 /-\eta .
$$

Standard oligopoly theory will lead to an analogous result in which industry concentration and conjectural variations about the responses of other firms will also enter on the right-hand side. ${ }^{31}$ From equation 4 , the percent change in the price-cost margin, $P \dot{C} M$, can be expressed as

$$
P \dot{C} M=\partial \eta /-\eta \text {. }
$$

Equation 5 says that changes in the monopolist's price-cost margin are a function of changes in the elasticity of demand. In this static model, if the demand elasticity is constant so that $\partial \eta=0$, then the monopolist will not change his price-cost margin regardless of changes in exchange rates or marginal costs. By definition then, the monopolist will fully pass through changes in these variables to foreign prices.

The same result can be obtained in another way from equation 3. If $\eta$ is constant, then $\Delta P / \Delta e$, the pass-through rate with respect to the exchange rate, will be a constant equal to $\lambda C^{\prime}$, and the pass-through elasticity with respect to the exchange rate change will equal $\lambda C^{\prime} e / P$, which equals the U.S. share in the total value added. If all value added were done in the United States, or if this elasticity were measured on a valueadded share weighted basis, then the pass-through elasticity would be one, signifying full pass-through.

In the "normal" case of a linear demand curve, however, demand becomes more elastic as price rises. When costs fall, the changes will be reflected in lower prices; but, because demand becomes less elastic, firms raise their markups and thus prices fall proportionately less than

31. See Waterson (1984, pp. 19-20). 
costs. ${ }^{32}$ The converse applies for rising costs and prices. In general, oligopolistic exporters would experience rising profit margins when the exchange rate depreciates and falling profit margins when the exchange rate appreciates. When such behavior is destination-specific-leading to a divergence between changes in prices at home and abroad-then in Krugman's words, the firm is "pricing to market." ${ }^{33}$ As we noted above, such behavior appears to be a feature of foreign exporters.

These considerations normally lead to a testing framework using a cost-plus markup specification..$^{34}$ If we were to follow the tradition of the existing literature, then our approach for the study of U.S. multinationals' foreign price behavior would be to regress the final product prices of these enterprises on their U.S. and foreign costs as in equation 3. However, explicit price data for the foreign sales of U.S. multinationals are not available. One approach is to estimate these prices using information on the volume of sales of U.S. multinationals abroad. ${ }^{35}$ An alternative approach is to test the model using the price-cost margin specification; this is the approach we will follow here.

We specify and estimate a function in which we regress changes in the price-cost margin against changes in U.S. exchange rates and costs, and foreign costs and competitor prices. We assume

$$
\Delta P C M=f\left(\Delta \tilde{e}, \Delta C^{\prime}, \Delta C^{* \prime}, \Delta F^{*}\right),
$$

where $C^{\prime}$ is the portion of the marginal cost incurred in the United States, $\tilde{e}$ is the nominal exchange rate in dollars per unit of foreign currency (equal to $1 / e$ ),$C^{* \prime}$ is the portion of the marginal cost incurred in the foreign country, and $F^{*}$ is the price charged by foreign competitors. We then specify a linearized version:

$$
P \dot{C} M_{i t}=\psi_{0}+\psi_{1} \dot{\tilde{e}}_{i t}+\psi_{2} P \dot{P} I_{i t}^{\mathrm{US}}+\psi_{3} P \dot{P} I_{i t}^{*}+\omega_{i t},
$$

32. Feenstra (1989, p. 29), Marston (1990) and Knetter (1992, p. 69) have indicated that more convex demand schedules are less plausible.

33. Krugman (1987). Management scholars C. K. Prahalad and Yves L. Doz (1987, p. 46) have something similar in mind when they argue that "It is important to realize that prices are constrained by market structures, competitive rivalry and competitors' strategic intentions in a given market and not just by cost to the firm. . .."

34. See Hooper and Mann (1989).

35. An exercise along these lines is presented in Rangan (forthcoming). It reaches conclusions similar to those presented here. 
where $i$ is an industry subscript, $t$ is a period subscript, dots over variables indicate percent changes, $P P I$ refers to the producer price index, and $\omega_{i t}$ is an error term. We assume that $P P I_{i}^{U S}$ reflects industry-specific U.S.-based marginal costs, and that $P P I_{i}^{*}$ reflects both foreign-based marginal costs and foreign competitors' prices. For each industry, the variable for foreign producer prices is a weighted average of producer prices in each of the nine major countries where U.S. majority-owned foreign affiliates (MOFAs) operate. The weights for each country are that country's share in the total sales of the industry. The nominal exchange rate variable-measured in dollars per unit of foreign currencyis measured in a similar way. For each industry, this variable is a weighted average of exchange rates for each of the nine countries. Again, the weights for each country are the country's share in the total sales of the industry. ${ }^{36}$

Equation 5 indicates that the dependent variable, the percent change in $P C M$, is equal to the percent change in the elasticity of demand. Thus if the demand elasticity (and the markup) were constant, then none of the coefficients in equation 7 would differ from zero. This is what one would expect to find according to the conventional wisdom that U.S. firms simply pass through exchange rate and other costs into their foreign prices.

However, if in fact U.S. firms do price to market, raising their pricecost margins when the dollar depreciates, one would expect to find a statistically significant positive coefficient on the exchange rate (because $\tilde{e}$ is measured in dollars per unit of foreign currency). Similarly, with such pricing-to-market behavior, higher U.S. costs would be associated with a reduction in price-cost margins and one would expect a negative coefficient on this variable. By the same logic, higher foreign prices would raise price-cost margins, leading to a positive coefficient. ${ }^{37}$

36. Country coverage is limited by the fact that the Commerce Department reports industry by country data for only nine countries: Australia, Canada, France, Germany, Italy, Japan, the Netherlands, Switzerland, and the United Kingdom. Together, they accounted for 74 percent of the $\$ 500$ billion in sales that U.S. majority-owned foreign affiliates in manufacturing made worldwide in 1989 (U.S. Bureau of Economic Analysis, 1991, Preliminary Results, table 33).

37. To conserve degrees of freedom, equation 7 constrains the exchange rate coefficient to be the same across all industries. In fact, firms in different manufacturing industries are likely to show different propensities to price to market depending on the demand curves they face, the importance of sunk costs, and market share. See Krugman (1987) and Dornbusch (1987). 
ESTIMATION. The basic equation was estimated for data on U.S. majority-owned foreign affiliates in fourteen manufacturing industries from 1983-89. ${ }^{38}$ Each observation is a year-to-year percent change in the dependent and independent variables for each industry. Price-cost margins for individual industries are calculated under the assumption that marginal cost is equal to average variable cost for each firm. ${ }^{39}$ Thus

$$
\text { PCM }_{i}=\left(\text { Sales }_{i}-\text { COGS }_{i}\right) / \text { Sales }_{i},
$$

where COGS stands for costs of goods sold and includes labor and material costs. Dividing each term on the right-hand side of equation 8 by the quantity sold gives the industry gross profit to revenue ratio,

$$
P C M_{i}=\left(P_{i}-A V C_{i}\right) / P_{i},
$$

where $P_{i}$ is the price and $A V C_{i}$ is the average variable cost for a given industry.

To show the variation by industry in the dependent variable, table 1 displays the estimated 1985 price-cost margins of U.S. manufacturing majority-owned foreign affiliates for a variety of industries. The pricecost margins in the table are well within the range that Ian Domowitz and his colleages found to be reasonable under assumptions of monopoly and oligopoly. ${ }^{40}$ Based on their findings, most of the margins in table 1 are low enough to suggest oligopolistic market structures, except perhaps for drugs, beverages, and printing and publishing, which have margins high enough to be consistent with monopolistic structures.

\section{Results}

Table 2 reports estimates of equation 7 for the overall period between 1983 and 1989, and separate estimates for the periods of dollar depreciation and appreciation. In general, the estimated coefficients on the exchange rate variable provide strong support for the pricing-to-market hypothesis and a rejection of the full pass-through view. The estimated

38. The starting date of 1983 was dictated by the availability of data.

39. This assumption is routinely made in the literature to get around the lack of data on marginal costs. See Waterson (1984, pp. 19-20) and Domowitz, Hubbard, and Petersen (1987, pp. 383-5). Recent work by Domowitz, Hubbard, and Petersen (1988, p. 58) concludes that this assumption is empirically tenable.

40. Domowitz, Hubbard, and Petersen (1987). 
Table 1. Price-Cost Margins of Selected Industries for U.S. Manufacturing MajorityOwned Foreign Affiliates, 1985

Ratio

\begin{tabular}{cc}
\hline \multicolumn{1}{c}{ Industry } & $\begin{array}{c}\text { Price-cost } \\
\text { margin }\end{array}$ \\
\hline Manufacturing & 0.22 \\
Food and kindred products & 0.27 \\
Beverages & 0.42 \\
Chemicals and allied products & 0.28 \\
Industrial chemicals and synthetics & 0.15 \\
Drugs & 0.44 \\
Primary and fabricated metals & 0.20 \\
Machinery, except electrical & 0.31 \\
Office and computing machines & 0.37 \\
Electric and electronic equipment & 0.19 \\
Household appliances & 0.28 \\
Electronic components and accessories & 0.15 \\
Motor vehicles and equipment & 0.08 \\
Tobacco products & 0.36 \\
Lumber and furniture & 0.19 \\
Printing and publishing & 0.45 \\
Glass products & 0.19 \\
Instruments and related products & 0.27 \\
\hline
\end{tabular}

Source: Authors' calculations using U.S. Bureau of Economic Analysis (1988, table 28).

magnitudes on the exchange rate coefficient (which range from 0.31 to 0.60 ) appear plausible and these coefficients are statistically significant, except in the fourth specification. Furthermore, as might be anticipated, ${ }^{41}$ the results imply that pass-through behavior in response to changes in the exchange rate is quite similar to that in response to changes in U.S. costs.

As table 2 shows, the results in the fourth specification, the 1983-85 appreciation phase, appear weakest. But a standard Chow test indicates that the coefficients during the appreciation periods are not significantly different from those in the later depreciation period. ${ }^{42}$ Thus, while the results in the fourth specification taken alone do not allow one to reject the hypothesis that U.S. firms practiced full pass-through during the

41. See Knetter (1992, p. 68).

42. The F-test for equality of coefficients was conducted after pretesting for equality of variances. See Maddala (1992, p. 177). The null hypothesis of equality of coefficients could not be rejected at the 5 percent level. 
Table 2. Regressions Explaining Changes in Price-Cost Margins for U.S. Manufacturing Majority-Owned Foreign Affiliates, 1983-89 ${ }^{a}$

\begin{tabular}{|c|c|c|c|c|c|}
\hline Independent variable & $\begin{array}{c}\text { Dollar } \\
\text { depreci- } \\
\text { ating, } \\
1986-89\end{array}$ & $\begin{array}{c}\text { Dollar } \\
\text { depreci- } \\
\text { ating, } \\
1986-89\end{array}$ & $\begin{array}{l}\text { Entire } \\
\text { period, } \\
1983-89\end{array}$ & $\begin{array}{c}\text { Dollar } \\
\text { appreci- } \\
\text { ating, } \\
1983-85\end{array}$ & $\begin{array}{c}\text { Entire } \\
\text { period, } \\
1983-89\end{array}$ \\
\hline Constant & $\begin{array}{c}-0.40 \\
(-0.16)\end{array}$ & $\begin{array}{c}0.60 \\
(0.28)\end{array}$ & $\begin{array}{c}0.57 \\
(0.36)\end{array}$ & $\begin{array}{l}1.54 \\
(0.35)\end{array}$ & $\begin{array}{l}-3.28 \\
(-1.17)\end{array}$ \\
\hline Nominal exchange rate & $\begin{array}{c}0.44 \\
(3.17)\end{array}$ & $\ldots$ & $\begin{array}{c}0.31 \\
(3.42)\end{array}$ & $\begin{array}{c}0.60 \\
(0.94)\end{array}$ & $\begin{array}{c}0.54 \\
(3.54)\end{array}$ \\
\hline U.S. producer prices ${ }^{d}$ & $\begin{array}{l}-0.16 \\
(-0.52)\end{array}$ & $\ldots$ & $\begin{array}{l}-0.44 \\
(-1.78)\end{array}$ & $\begin{array}{l}-0.51 \\
(-0.99)\end{array}$ & $\begin{array}{l}-0.49 \\
(-2.67)\end{array}$ \\
\hline $\begin{array}{c}\text { Exchange rate/U.S. } \\
\text { producer prices }\end{array}$ & $\cdots$ & $\begin{array}{c}0.38 \\
(3.47)\end{array}$ & $\ldots$ & $\ldots$ & . \\
\hline Foreign producer prices ${ }^{d}$ & $\begin{array}{c}0.17 \\
(0.31)\end{array}$ & $\begin{array}{c}0.26 \\
(0.51)\end{array}$ & $\begin{array}{c}0.73 \\
(1.83)\end{array}$ & $\begin{array}{c}1.17 \\
(1.76)\end{array}$ & $\begin{array}{c}1.64 \\
(1.93)\end{array}$ \\
\hline $\begin{array}{l}\text { Summary statistic } \\
\overline{\mathrm{R}}^{2}\end{array}$ & 0.17 & 0.18 & 0.10 & 0.01 & 0.89 \\
\hline Number of observations & 56 & 56 & 98 & 42 & 7 \\
\hline
\end{tabular}

Source: Authors' regressions using nominal exchange rate data from International Financial Statistics (rf quotes). Data on country shares by industry are from U.S. Bureau of Economic Analysis (1989, Benchmark Survey, table 33). U.S. and foreign industry-specific producer price change data are estimated from OECD (various issues).

a. The regressions are based on equation 7 in the text. The dependent variable is the percent change in the pricecost margin. The numbers in parentheses are $t$-statistics. Manufacturing industries included in the regressions are: food and kindred products; chemicals and allied products; fabricated metal products; machinery except electrical; electric and electronic products; motor vehicles and equipment; tobacco products; textile products and apparel; lumber and furniture; paper and allied products; printing and publishing; glass products; stone, clay, and related; and instruments and related.

b. All independent variables are expressed as year-to-year percent changes.

c. The nominal exchange rate is defined as dollars per unit of foreign currency. Industry-specific exchange rates are fixed weight, average changes in nominal exchange rates across the nine major countries (see text) that host U.S. majority-owned foreign affiliates (MOFAs). Country weights for each industry are based on 1989 country shares in U.S. MOFAs' sales in that particular industry.

d. Producer prices are for the fixed weight index of manufactured goods, excluding computers. Country weights used for estimating changes in industry-specific foreign producer prices are the same as those used above for estimating exchange rate changes.

1983-85 period, the results of the Chow test do not allow one to reject the hypothesis that U.S. firms responded similarly to the dollar appreciation and depreciation. Moreover, we have convincing evidence that, over the period as a whole, the hypothesis of complete pass-through can be rejected. Finally, the pass-through behavior implied by these results is well within the range of that reported in the literature for foreign firms competing in U.S. markets. ${ }^{43}$ It appears that "U.S. firms" are not so different after all.

43. See Alterman (1991), Hooper and Mann (1989), Marston (1991), and Moffett (1989). 
Table 3. Simulating the Pass-through Response of U.S. Majority-Owned Foreign Affiliates to a 10 Percent Decline in the U.S. Dollar ${ }^{a}$

\begin{tabular}{|c|c|c|c|c|c|c|}
\hline & \multicolumn{6}{|c|}{ Price-cost margin elasticity ${ }^{\mathrm{b}}$} \\
\hline & 0.00 & 0.31 & 0.38 & 0.44 & 0.54 & 0.60 \\
\hline New price-cost margin ${ }^{c}$ & 0.22 & 0.23 & 0.23 & 0.23 & 0.24 & 0.24 \\
\hline New price ${ }^{d}$ & 0.98 & 0.99 & 0.99 & 0.99 & 1.00 & 1.00 \\
\hline Percent change in costs & -2.00 & -2.00 & -2.00 & -2.00 & -2.00 & -2.00 \\
\hline Percent change in price & -2.00 & -1.12 & -0.91 & -0.74 & -0.45 & -0.27 \\
\hline Pass-through rate $\mathrm{e}^{\mathrm{e}}$ & 1.00 & 0.56 & 0.46 & 0.37 & 0.22 & 0.14 \\
\hline $\begin{array}{l}\text { Imputed demand } \\
\text { elasticity }\end{array}$ & 1.12 & 1.08 & 1.08 & 1.07 & 1.06 & 1.05 \\
\hline
\end{tabular}

Source: Authors' calculations based on results from table 3 and U.S. Bureau of Economic Analysis (1988, table 28 , columns 1 and 7 , and table 51 , column 1 ).

a. Initial U.S. and foreign costs in 1985 accounted for 15.5 and 62.1 percent of total value added. The difference of 22.4 percent represented the initial price-cost margin.

b. These price-cost margin elasticities are based on the regressions shown in table 3 .

c. The new price-cost margin $(\mathrm{PCM})$ equals (initial PCM) $\times[1.0+(0.10 \times \mathrm{PCM}$ elasticity) $]$.

d. The new price equals (new costs)/(1.0 - new PCM) where new costs equal (initial U.S. costs $\times 0.90$ ) plus initial foreign costs.

e. The pass-through rate is the percentage change in price divided by the percentage change in costs.

f. The imputed demand elasticity is an assumed Herfindahl index value of 0.25 divided by the new price-cost margin.

To help interpret the results shown in table 2 , we provide a simulation spreadsheet in table 3 that takes the coefficients on the exchange rate variable from table 2 and uses them to impute exchange rate passthrough ratios. For initial conditions, we use the 1985 data on the cost structure of U.S. MOFAs, when U.S. costs accounted for 15.5 percent of value added and 20 percent of total cost of goods sold. From equation 4 , it follows that if U.S. MOFAs were all monopolies in their respective foreign markets, then an average price-cost margin of 22.4 percent corresponds to a demand elasticity of 4.46. In the more realistic case of oligopoly, with a Herfindahl index of 0.25 , these data correspond to a demand elasticity of 1.12 (see table 3 ).

The table simulates the effect of a 10 percent decline in the U.S. dollar's exchange rate on foreign currency prices, under the different elasticities of the price-cost margin estimated in table 2 . Consider the first column in table 3 when the elasticity of the price-cost margin with respect to the exchange rate is taken to be zero-a case representing the extreme form of the conventional wisdom. In this case, the PCM will remain unchanged. Hence, given a 20 percent share in total costs of goods sold, the 10 percent fall in the dollar lowers total costs of goods sold by 2 percent. With the markup unchanged, prices also fall by 2 per- 
cent, giving a pass-through rate equal to unity. Note, however, that because of the small U.S. share in total value added, even under complete pass-through, the foreign currency prices charged by U.S. multinationals decline by only 2 percent in the face of a 10 percent fall in the value of the U.S. dollar.

Next we simulate cases in which the PCM elasticity corresponds to the exchange rate coefficients (from smallest to largest) that we have estimated in our regressions in table 2. With a PCM elasticity of 0.31 (taken from the third specification in table 2), prices decline by only 1.12 , rather than 2.00 percent as under full pass-through. This implies a pass-through rate of 0.56 . With a PCM elasticity of 0.38 (taken from the second specification in table 2 ), prices decline by only 0.91 percent, which implies a pass-through rate of 0.46 . In general, larger PCM elasticities result in smaller pass-through and larger increases in markups.

The actual nominal effective depreciation of the U.S. dollar between 1985 and 1989 was 31 percent. However, as the simulation in table 3 shows, even if U.S. firms had fully passed this through into their final sales prices, on average their prices in foreign markets would have declined by only 6.2 percent. In fact, given the estimated elasticity of 0.31 in the third specification in table 2 , the average decline in prices would have been only 3.5 percent $(0.56 \times 6.2$ percent $)$. Thus our evidence shows why a majority of major U.S. exporting firms surveyed indicated that they had "maintained" their foreign currency prices-even in the face of this major exchange rate shift.

Of course, if U.S. products were simply distributed by U.S. foreign affiliates, the price declines, although a small share of total sales, would be more conspicuous than if they were intermediate inputs and thus a small share of the value of each final product sold. But, in fact, the 1989 data indicate that about 82 percent of the imports received by U.S. MOFAs in the manufacturing industry are inputs for further value added-which supports the interpretation of these products as intermediate inputs, rather than final sales. ${ }^{44}$

To summarize, these results suggest quite strongly that U.S. firms abroad vary their price-cost margins in response to changes in the dollar's exchange rate. The estimated results suggest pass-through rates of 14 to 60 percent. The size of these estimates is consistent with those

44. This is shown in the last bar in figure 3 . 
made by other researchers for foreign firms competing in U.S. markets; we can reject the view that U.S. firms fully pass through and do not price to market.

\section{Sourcing Behavior of U.S. Multinationals}

Economists have long debated whether multinationals present an impediment to the macroeconomic adjustment process initiated by exchange rate changes. ${ }^{45} \mathrm{~A}$ central question in this debate has been whether the intrafirm trade of multinational enterprises responds in the anticipated direction and with the degree of elasticity exhibited by arm's-length trade.

The literature offers views on every side of the issue. Some authors predict that intrafirm trade has slow and small responses because activities among firms reflect hierarchical or command behavior and are not as sensitive to market considerations as arms-length transactions. ${ }^{46}$ Others predict that intrafirm trade has relatively large and more rapid responses because multinationals have ready access to production capacity, both at home and abroad, which allows them to respond effectively to cost changes brought about by exchange rate fluctuations. ${ }^{47} \mathrm{~A}$ third view, presented by C. Fred Bergsten and his colleagues, maintains that "there is no compelling reason to believe that [multinationals] react differently" to exchange rate changes. ${ }^{48}$

The large depreciation of the U.S. dollar during the latter half of the 1980s provides a natural experiment to test these views. Consider table 4. As the first two columns of this table show, the value of U.S. intrafirm manufacturing exports grew at rapid pace of 47 percent during this four-year period, but this was still less than the 65 percent increase in overall U.S. manufacturing exports. ${ }^{49}$ This comparison suggests that

45. See Bergsten, Horst, and Moran (1978), especially chapter 8.

46. See Goldsbrough (1981), Helleiner (1981, p. 3), Little (1986, p. 46), Cho (1990), and Encarnation (1992).

47. See Knetter (1992, 1993), Lipsey and Kravis (1986), Little $(1986,1987)$, and Marston (1991).

48. Bergsten, Horst, and Moran (1978, p. 285).

49. The aircraft and parts industry is excluded from this analysis because there is almost no intrafirm trade in this industry, for reasons related to scale economies and national security. If this industry were included in the growth rate calculation, overall U.S. manu- 
Table 4. Growth in Overall U.S. Manufacturing Exports and U.S. Parents' Intrafirm Exports, 1985-89

Percent

\begin{tabular}{|c|c|c|c|c|c|c|}
\hline \multirow[b]{2}{*}{ Industry } & \multicolumn{2}{|c|}{$\begin{array}{c}\text { Unweighted change } \\
\text { in manufacturing } \\
\text { exports }\end{array}$} & \multicolumn{2}{|c|}{$\begin{array}{l}\text { Industry share of } \\
\text { manufacturing } \\
\text { exports }^{\mathrm{a}}\end{array}$} & \multicolumn{2}{|c|}{$\begin{array}{c}\text { Industry share } \\
\text { weighted change in } \\
\text { manufacturing } \\
\text { exports }\end{array}$} \\
\hline & $\begin{array}{c}\text { U.S. } \\
\text { overall }\end{array}$ & $\begin{array}{l}\text { U.S. parents' } \\
\text { intrafirm }\end{array}$ & $\begin{array}{c}\text { U.S. } \\
\text { overall }\end{array}$ & $\begin{array}{l}\text { U.S. parents' } \\
\text { intrafirm }\end{array}$ & $\begin{array}{c}\text { U.S. } \\
\text { overall }\end{array}$ & $\begin{array}{l}\text { U.S. parents } \\
\text { intrafirm }\end{array}$ \\
\hline All manufacturing ${ }^{\mathrm{c}}$ & 65.4 & 47.0 & 100.0 & 100.0 & 51.5 & 50.5 \\
\hline Food and kindred products & 47.4 & 23.6 & 6.5 & 2.1 & 1.0 & 0.5 \\
\hline Tobacco & 186.4 & 139.4 & 1.3 & 0.3 & 0.6 & 0.4 \\
\hline Textiles and apparel & 113.6 & 125.0 & 2.0 & 0.3 & 0.3 & 0.4 \\
\hline Lumber and furniture & 123.6 & 91.8 & 2.7 & 0.2 & 0.3 & 0.2 \\
\hline Paper and allied products & 102.9 & 294.8 & 3.1 & 0.7 & 0.8 & 2.2 \\
\hline Printing and publishing & 77.3 & 21.5 & 0.9 & 0.3 & 0.2 & 0.1 \\
\hline Chemicals and allied products & 64.4 & 65.6 & 15.1 & 14.0 & 9.0 & 9.2 \\
\hline Rubber products and plastics & 60.7 & 41.6 & 1.9 & 1.2 & 0.7 & 0.5 \\
\hline Stone, clay, glass, and concrete & 63.7 & 41.9 & 1.2 & 0.5 & 0.3 & 0.2 \\
\hline Primary metals & 136.9 & 54.2 & 4.2 & 1.1 & 1.5 & 0.6 \\
\hline Fabricated metals & 49.4 & 43.5 & 3.8 & 0.8 & 0.4 & 0.3 \\
\hline Machinery, except electrical & 45.5 & 74.1 & 24.0 & 26.2 & 11.9 & 19.4 \\
\hline Electrical equipment & 78.9 & 21.0 & 13.8 & 10.1 & 8.0 & 2.1 \\
\hline Motor vehicles and parts & 26.7 & 25.3 & 10.6 & 35.4 & 9.4 & 8.9 \\
\hline Instruments and related parts & 99.8 & 84.8 & 6.8 & 6.5 & 6.5 & 5.5 \\
\hline Other & 168.7 & -16.0 & 2.2 & 0.3 & 0.6 & -0.1 \\
\hline
\end{tabular}

Source: U.S. export data are from U.S. Bureau of Census and U.S. Bureau of Labor Statistics (1988, table 5, and 1992, table 5). Intrafirm export data are from U.S. Bureau of Economic Analysis (1988, table 57, column. 4) and U.S. Bureau of Economic Analysis (1991, table 85, column 6).

a. Exports in 1985 and 1989 for a given manufacturing industry were added together and then divided by the sum total of 1985 and 1989 manufacturing exports in all industries.

b. Weights used are the share of U.S. parents' intrafirm manufacturing exports.

c. Excludes petroleum and transportation equipment other than motor vehicles and parts.

intrafirm exports responded less to the decline in the dollar than armslength exports. These results support the findings of Jane Sneddon Little, who concluded that intrafirm exports are far less sensitive than arm's-length exports. She found that in response to the dollar appreciation between 1982 and 1984, intrafirm exports grew by 27 percent, but that the rising dollar held down the growth in arm's-length exports enough to keep overall manufacturing export growth to only 4 percent during this period. ${ }^{50}$

factured exports would grow by 65.6 percent, while intrafirm exports would grow by 47.6 percent. These growth rates do not differ significantly from the nonaircraft export growth rates presented in this paper.

50. Little (1987, table 2, p. 48). 
However, these simple comparisons need to be interpreted cautiously. Responsiveness to exchange rates can be expected to differ by industry; therefore, these comparisons could capture changes in industry mix, rather than the impact of intrafirm trade per se. Indeed this is the case. As the middle two columns of table 4 show, intrafirm trade is heavily concentrated in only five two-digit SIC industries: chemicals and allied industries; machinery (except electrical); electrical equipment and supplies; motor vehicles and parts; and instruments and related products. These industries account for 92 percent of U.S. intrafirm exports, but only 70 percent of overall U.S. manufacturing exports.

In fact, at the individual industry level, the data in the first two columns of the table indicate very similar overall and intrafirm growth rates: 64.4 and 65.6 percent in chemicals; 26.7 and 25.3 percent in motor vehicles; 99.8 and 84.8 percent in instruments; and although large differences do persist in the nonelectrical and electrical machinery industries, these differences do not, on balance, suggest greater responsiveness of arm's-length exports. In nonelectrical machinery, arm's-length exports grew much faster. Curiously, when these two industries are taken together as one-machinery-overall and intrafirm growth rates converge at 56.7 and 56.9 percent, respectively (not shown in the table) ${ }^{51}$ Industry mix is accounted for formally in the fifth and sixth columns, which weight each industry's growth rate by its share in intrafirm exports. Comparing the top figures in each column shows that once industry mix is taken into account, there is virtually no difference between the growth rates of intrafirm and arm's-length exports. Our analysis for the late 1980 s, therefore, lends support to the views of Bergsten, Horst, and Moran, who argued that multinational corporations do not react differently to exchange rate changes.

Earlier in the paper, we noted two important features of intrafirm trade. First, more than 80 percent of such shipments are intermediate products used as inputs by overseas affiliates. Second, products from the United States account for less than 20 percent of the overall value of the sales of U.S. overseas affiliates. We also provided evidence that only about half of the dollar's depreciation is passed through into final prod-

51. We hypothesize that the apparent difference in intrafirm and arm's-length export growth rates in electrical and nonelectrical machinery is due to differences in classification, not behavior. For further elaboration and some supporting evidence, see Rangan (forthcoming). 
uct prices. On average, therefore, a 40 percent reduction in dollar marginal costs would lower foreign prices by only 4.0 percent $(0.5 \times 0.2 \times$ 40). If U.S. content remained a fixed share of foreign sales, then we would not expect much of an impact on U.S. exports operating through this channel. Yet as we have seen, in fact, intrafirm exports increased considerably. This suggests that much of the adjustment took the form of sourcing adjustments by U.S. multinational corporations. As we will now demonstrate, U.S. multinationals raised the U.S. content of their output in a manner that is consistent with a substitution response to the weaker dollar.

Table 5 reports data on the operations of U.S. MOFAs in the manufacturing industry in eighteen countries, which account for nearly 90 percent of all sales made by U.S. manufacturing MOFAs worldwide. ${ }^{52}$ The last column of data indicates that the level of estimated U.S. content in products sold by U.S. MOFAs rose between 1985 and 1989 in ten of the countries considered..$^{53}$ Further, in Malaysia and Singapore, where U.S. content levels did not rise, the U.S. dollar appreciated vis-à-vis the domestic currency. So in two-thirds of the countries, the substitution behavior of U.S. multinationals was in keeping with a priori expectations, given movements in the real exchange rate..$^{54}$

Figure 4 plots the changes in the U.S. content levels in seventeen of these countries against the changes in real exchange rates. Rising U.S. content levels covary with falling values of the dollar. In fact, ordinary least squares regression, where $E$ is the U.S. dollar's real exchange rate in dollars per foreign currency unit, gives the following result:

$$
\begin{gathered}
U \dot{S} \text { content }=\begin{array}{c}
0.27+1.25 \dot{E} \\
(4.10) \quad(-2.78)
\end{array} \\
\bar{R}^{2}=0.50 ; \text { F-test }=16.82 ; \text { sample size }=17 \\
(t \text { - } \text {-statistics in parentheses })
\end{gathered}
$$

where dots over the variables indicate percent changes.

52. U.S. Bureau of Economic Analysis (1991, Preliminary Results, table 32, col. 3).

53. Although the U.S. content levels shown in table 5 may, in and of themselves, merit further exploration in terms of what they signal about the strategy of U.S. multinationals in various countries (and possibly industries), this issue is not taken up here.

54. Of the remaining six countries where behavior did not match a priori expectations, three-Hong Kong, the Philippines, and Taiwan-are newly industrialized countries. For these countries, factors other than the exchange rate were probably important, including improvements in their productive competitiveness. 
Table 5. Operations of U.S. Majority-owned Foreign Affiliates (MOFAs) in Eighteen Countries, 1985-89

Percent

\begin{tabular}{|c|c|c|c|c|}
\hline \multirow[b]{2}{*}{ Country } & \multirow{2}{*}{$\begin{array}{c}\text { Change } \\
\text { in U.S. } \\
\text { dollar } \\
\text { real } \\
\text { exchange } \\
\text { rate, } \\
1985-89\end{array}$} & \multicolumn{3}{|c|}{ U.S. content in MOFAs ${ }^{\mathrm{a}}$} \\
\hline & & 1985 & 1989 & $\begin{array}{c}1985 \text { to } \\
1989 \\
\text { change }\end{array}$ \\
\hline Canada & 17.0 & 40.6 & 38.9 & -4.2 \\
\hline Belgium & 26.2 & 12.4 & 11.7 & -5.7 \\
\hline France & 39.9 & 6.3 & 6.4 & 1.8 \\
\hline Germany & 42.9 & 5.3 & 6.9 & 31.8 \\
\hline Ireland & 32.3 & 24.3 & 22.3 & -8.4 \\
\hline Italy & 45.0 & 5.1 & 6.9 & 37.1 \\
\hline Netherlands & 43.9 & 10.0 & 13.3 & 31.9 \\
\hline United Kingdom & 38.3 & 7.2 & 8.2 & 14.9 \\
\hline Spain & 44.1 & 3.0 & 11.8 & 298.9 \\
\hline Switzerland & 42.6 & 4.9 & 8.7 & 77.7 \\
\hline Japan & 41.1 & 10.5 & 14.6 & 38.6 \\
\hline Australia & 34.9 & 10.1 & 11.1 & 10.0 \\
\hline Hong Kong & 18.0 & 22.3 & 15.1 & -32.4 \\
\hline Malaysia & -10.3 & 44.8 & 26.6 & -40.6 \\
\hline Philippines & 6.0 & 21.6 & 18.5 & -14.4 \\
\hline Singapore & -4.7 & 28.8 & 27.5 & -4.3 \\
\hline South Korea & 22.9 & 40.0 & 42.1 & 5.4 \\
\hline Taiwan & 29.0 & 17.1 & 13.8 & -19.2 \\
\hline
\end{tabular}

Source: U.S. exports to MOFAs is from U.S. Bureau of Economic Analysis (1988, table 52, column 3; 1989, Preliminary Results, table 68, column 3). Export prices by sector are an unpublished series from the U.S. Bureau of Labor Statistics entitled "U.S. Export Dollar Price, Average Exchange Rate, and Foreign Currency Price Indexes $(1985=100)$." Period averages are used for 1989. Industry weights used in export price calculations are from U.S. Bureau of Economic Analysis (1991, table 66). Cost of goods sold data for 1985 and 1989, respectively, are from U.S. Bureau of Economic Analysis (1988, table 27, columns 8 and 10; table 29, column 3; and table 31, column 3). Exchange rate data are from International Financial Statistics (rf quotes), unpublished data from the Federal Reserve (for Taiwan), and the United Nations (for Hong Kong). Producer prices are from OECD (1992:2); World Bank, World Tables; and United Nations (1991). Producer price index weights are from U.S. Bureau of Economic Analysis (1987, table 29).

a. U.S. content level of U.S. MOFAs in any particular country is measured by dividing the quantity of U.S. imports that these MOFAs make in a given year by the total cost of goods sold in the same year.

These results suggest that, ceteris paribus, over this period, every 1 percent drop in the U.S. dollar's real exchange rate leads to a 1.25 percent rise in the U.S. content level of U.S. manufacturing MOFAs. This estimated elasticity coefficient of 1.25 passes the standard $t$-test at the 99 percent level and, together with a constant term, explains half the total variation in changes in U.S. content levels between 1985 and 1989. A similar regression that estimates the U.S.-to-local content response-or 
Figure 4. Change in the Real Exchange Rate and U.S. Content Levels in Majorityowned Foreign Affiliates, 1985-89

Percent change in U.S. content levels ${ }^{a}$

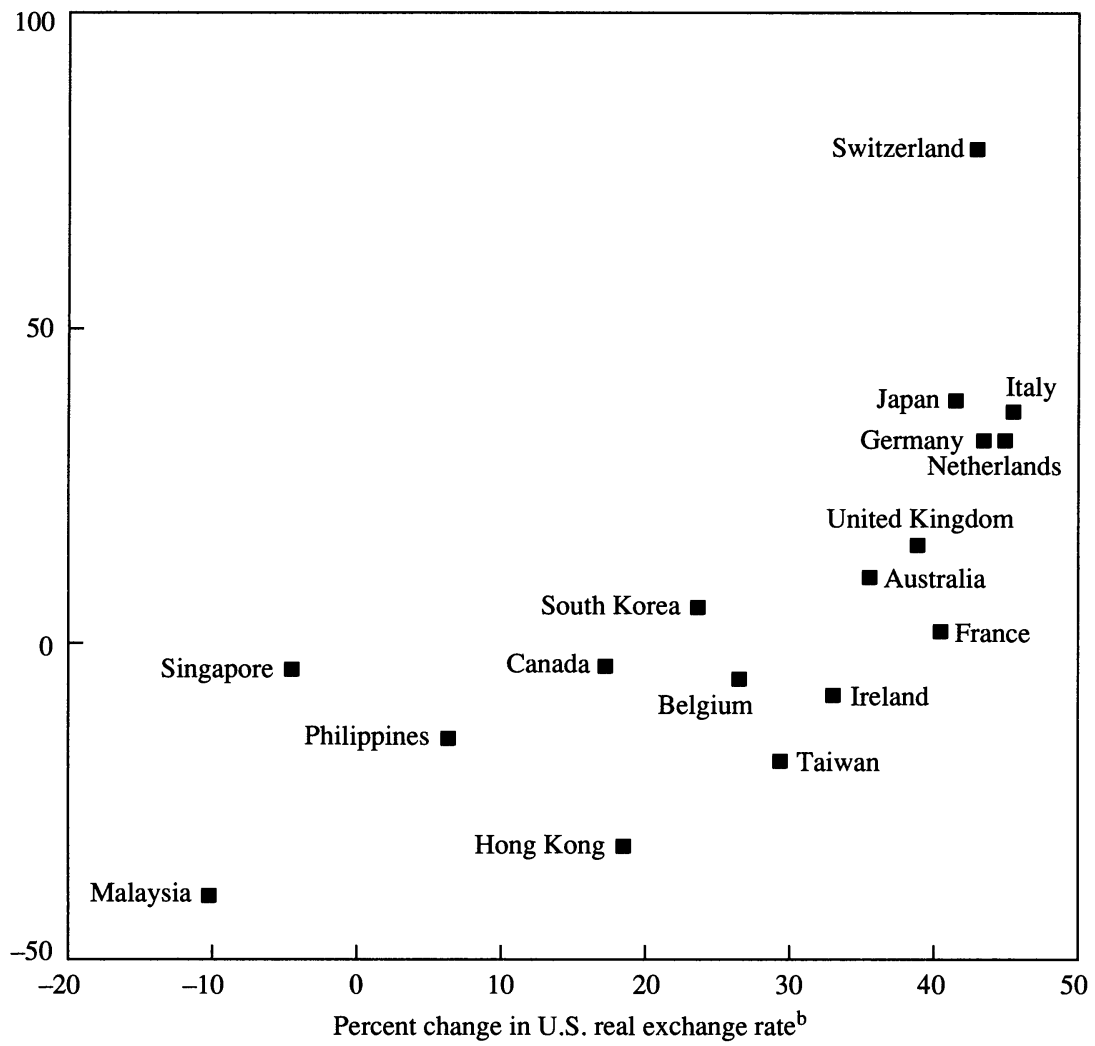

Source: Authors' calculations based on table 5 and Rangan (forthcoming).

a. The percent change in U.S. content levels from 1985 to 1988 is the percent change in the share of U.S. content in products manufactured by MOFAs of U.S. parents.

b. The U.S. dollar's real exchange rate is denominated as U.S. dollars per foreign currency unit, so positive percent changes from 1985 to 1989 represent a real depreciation, while negative changes represent a real dollar appreciation.

the elasticity of substitution-yields an estimate of $1.48 .{ }^{55}$ This estimate is quite similar in magnitude to those found in conventional estimates of export price elasticity. ${ }^{56}$

55. See Rangan (forthcoming).

56. See Stern, Francis, and Schumacher (1976, p. 224). They cite Junz and Rhomberg (1965). 
A similar analysis can be carried out aggregating the data by industry rather than by country. Although we do not show the results, with the exception of U.S. MOFAs in the transportation equipment industry, MOFAs in all the other major industries responded quite vigorously to the depreciation of the dollar by raising their U.S. content levels. MOFAs in the more commodity-based industries, such as food and metals, exhibited a higher elasticity of substitution than those in the more differentiated industries, such as chemicals, nonelectrical machinery, and electric and electronic equipment. While MOFAs in these latter industries responded with an elasticity of around one, MOFAs in the food industry responded with an elasticity of two, and those in metals with an elasticity of just under two. ${ }^{57}$

We should end this section on a note of caution. Using the annual data on U.S. multinational operations has certain drawbacks. First, it is hard to distinguish changes in the aggregate that reflect new entry and exit of firms from changes that reflect expansion of existing operation. Second, because each firm is classified in only one industry, changes in a firm's product mix can shift a firm's classification, further complicating the interpretation of the more aggregate data. ${ }^{58}$ Nonetheless, the best available data do suggest that in the second half of the 1980s, U.S. multinationals in most industries and countries added to the U.S. content of their products sold abroad.

57. U.S. MOFAs in the automobile industry did not respond to the large exchange rate change. In fact, what little responsiveness they showed appears to be in the "wrong" direction. That is, these MOFAs seem to have lowered their U.S. content levels between 1985 and 1989. The motor vehicles and parts industry is very special because the bulk of U.S. exports and investment in this industry take place under specific agreements with Canada and Mexico. For a recent treatment of this issue, see Eden and Molot (1992). These agreements constrain the adjustment possibilities of U.S. firms, particularly with regard to switching out of local content. For instance, the U.S. agreement with Mexico stipulates that every $\$ 1$ of car imports brought into the country by U.S. MOFAs in Mexico must be matched by $\$ 2$ of exports; the ratio for auto parts is $1: 1$ (Hufbauer and Schott, 1993, p. 39). Similar local content rules are imposed by Canada stipulating that for every car sold in Canada, a car must be made in Canada (Eden and Molot, 1992).

58. If product-mix changes accounted for the increase in U.S. content levels, then the industry mix of U.S. MOFAs should have changed noticeably between 1985 and 1989 in several countries. However, for each country, the Pearson coefficient of correlation between industry mix in 1985 and 1989 in these countries was very high and often close to 1 , with only two exceptions. 


\section{Concluding Comments}

We have presented evidence suggesting that U.S. multinationals behave in a manner consistent with a priori expectations. They allow their profit margins to cushion the effects of exchange rate changes on the prices they receive from foreign buyers. In addition, they adjust their sourcing in response to changes in marginal costs.

The study of macroeconomic relationships is fraught with difficulty and often requires ignoring complex institutional relationships. In particular, studies of exchange rate adjustment rarely pay attention to the role of multinational companies in the conduct of trade. We have argued here that the use of the BLS export price index to draw conclusions about market pricing behavior has led to misleading conclusions about how "U.S." firms price abroad. On the other hand, changes in sourcing, rather than a rise in total final sales, appear to be the major avenue by which the exchange rate affects intrafirm decisions. Because the BLS export price data provide a reasonable measure of changes in the marginal cost of producing in the United States, they have served fairly well in tracking the sourcing decisions of U.S. multinationals. 


\section{Comments and Discussion}

Richard N. Cooper: The paper by Subramanian Rangan and Robert Lawrence basically makes two contributions to a highly specialized but growing literature. The first involves some new estimates concerning the extent to which U.S. firms pass through foreign exchange rate changes in their pricing to foreigners. The second finding concerns the degree to which exchange rates influence sourcing by U.S. corporations.

I am going to comment mainly on the first finding, which is more controversial. On the second, Rangan and Lawrence's results are eminently reasonable, but basically they are drawn from one episode, the sharp devaluation of the U.S. dollar from 1985 to 1988. One always ought to be leery about generalizing from a single episode, even though in this case the results strike me as sensible.

The key to Rangan and Lawrence's first finding is their observation that a substantial fraction of U.S. international trade represents intrafirm trade. Roughly 40 percent of U.S. exports of manufactures is intrafirm trade, and one cannot infer from the price that is charged to the downstream affiliate of the same firm what price is actually charged to foreigners. Therefore, one cannot infer much about U.S. pricing strategy to foreigners from BLS data, which report U.S. export prices.

I will suggest some worthwhile extensions of Rangan and Lawrence's analysis, and then some implications of their results for how the world operates, on the one hand, and how economists theorize about how the world operates, on the other.

Rangan and Lawrence have focused on affiliated sales, but it would be useful also to look at nonaffiliated sales insofar as one can separate them from affiliated sales. Perhaps one could do that on an industry-byindustry basis since the extent of foreign investment varies greatly from 
practically none at all in civil aviation, for example, to very extensive in automobiles.

Figure 2 is suggestive on that score, but it is certainly not definitive. One would like to know whether the charge that U.S. firms merely accept orders, while foreign firms make an effort to sell abroad, applies to firms that do not have downstream sales to overseas affiliates.

An analogous question concerns imports into the United States. The arguments the authors adduce for intrafirm sales for U.S. firms presumably also apply to foreign firms selling in this country, and therefore, in principle, their prices would be subject to the same kinds of biases in reporting; the question is whether that is so. The same data set, basically -although less complete-is available for foreign investment in this country as it is for U.S. investment abroad. It would be interesting to run this exercise on that data set.

Let me express even more skepticism than the authors have expressed about the validity of the data we are using. The generalization that has emerged from earlier work is that, in contrast to U.S. firms, foreign firms price to market. That is to say, during the 1982-85 dollar appreciation, they fattened their margins on exports substantially, and during the subsequent 1985-89 dollar depreciation, they trimmed their margins substantially without adjusting their dollar prices.

Yet the share of imports of manufactured goods in U.S. final sales of manufactures rose sharply during the first half of the 1980s and declined during the second half of the 1980s. That is hardly consistent with a pricing-to-market strategy unless quality happened to rise in the first period and decline in the second.

I believe the pricing data on at least some imports are highly suspect, and they are suspect in part because nobody actually knows what the unit prices are, including the selling firms. Let me give an example. It is common practice in the consumer electronics industry for foreign manufacturers at year-end to provide substantial advertising and other allowances to their major customers. Those allowances are negotiated between buyer and seller, and they do not get recorded anywhere in the transactions prices, as far as I know. Yet, those rebates can be significant.

What I suspect happened in the early 1980s is that such indirect discounts rose substantially, giving the appearance of fattened margins by foreign exporters, while from 1985 to 1989 such discounts declined in 
relative importance. So on an economic basis there was greater price movement and less pricing to market than shows up in the statistics.

Let me turn to some of the broader issues raised by Rangan and Lawrence's paper. What is the sensible pricing strategy for a firm that sells abroad as well as domestically in a world of floating exchange rates? Most buyers and sellers do not like daily changes in prices, particularly for branded goods. But exchange rates change daily. What is the appropriate pricing strategy for exporting firms under those circumstances?

Firms face a dilemma: if they maintain a fixed ex-factory price for all customers, customers in other currency areas will face daily fluctuations in the prices they face (except insofar as importers absorb the fluctuations); if they maintain fixed prices within each market, that implies price discrimination among customers when measured in terms of the ex-factory price. Customers generally do not like fluctuating prices; nor do they like to be the targets of discrimination. Moreover, national authorities take a dim view of price discrimination, particularly when it is open to the charge of "dumping": that is, selling in the importing country at a lower price than prevails in the home market. Both the United States and the European Community have become very active in pursuing alleged dumping, and other countries have begun to emulate those two major markets. Moreover, U.S. antitrust authorities have historically been highly concerned about predatory pricing, although rather less so in the 1980s than during other periods. Not least, there is the question of the appropriate incentives to management in firms that, at least in the case of the United States, are large enough to be concerned about internal management of the firm. America's large exporting firms are typically multidivisional firms, for instance, and top management has to worry about maintaining discipline on the numerous decentralized decisionmakers in each firm.

So, what is the appropriate pricing strategy under these circumstances? From the point of view of maximizing profits, economists have taught for a long time that maximal price discrimination is desirable. "Divide up your customers as well as you can and scoop out the potential consumer surplus from each customer." That is not possible for most firms, for a variety of reasons, including the possibility of resale. What then are their second-best strategies?

One of them is to invest across currency areas so that the firm can do precisely what Rangan and Lawrence have pointed out that many firms 
do. They can follow one pricing strategy for the intrafirm international transactions and a quite different pricing strategy vis-à-vis their ultimate customers. The foreign affiliate becomes a kind of shock absorber, and the local knowledge that it has regarding customer behavior and elasticity of demand can be utilized by each of the affiliates. Overseas investment thus might be a sensible strategy even when the rate of return on that investment is lower than at home in terms of normal capital theory: that is, in physical terms.

A second strategy would be to differentiate the end products as much as possible in order to reduce the possibilities for arbitrage. From this point of view-provided it does not take too large a toll in terms of costs-having a metric system in Europe and the English measuring system in the United States is not all bad from the firm's point of view. Having fifty cycles at 220 volts in Europe and sixty cycles at 110 volts in the United States, or left-hand drive in Britain and right-hand drive on the Continent, is not all bad. Sony was probably the world's biggest beneficiary of three TV broadcasting systems because Sony can, at small cost, make the adjustments to each of the three systems and have quite different pricing strategies in Europe, United States, and at home in Japan.

A third strategy is that firms do whatever they can to prevent arbitrage. Arbitrage can undermine any price-discriminating strategy, and it is not an accident that in the mid-1980s a number of quite negative remarks were made about the emergence of gray markets in the United States.

What are gray markets? This funny category of market was developed and publicized by a number of firms, including Sony. Gray markets reflect arbitrage taking place by brokers, jobbers, and dealers outside of traditional marketing channels. It may be in a manufacturing firm's interest to inhibit that from happening. Michael Deaver made headlines in the mid-1980s by buying German cars on an official trip to Germany; they were much cheaper there because the high-quality German cars were being priced in dollars in the United States much higher than the DM prices converted at market exchange rates: that is, the German firms were engaging in price discrimination. Different safety standards permitted some market segmentation, but a conversion kit could be purchased relatively cheaply. After a time, arbitrage began to take place, as Deaver's highly publicized purchase suggests. 
The most egregious case of an attempt to segment markets that I am aware of is when Duracell brought a trademark infringement case against the importation of Duracell batteries from its wholly owned Belgian subsidiary. U.S. customs dismissed the charge, but Duracell had the gall to appeal to the Court of Customs Appeals. That court properly also threw it out. But the episode provides an example of how a firm can throw (legal) sand into the process of arbitrage. That is a sensible corporate strategy under these circumstances, even if it is not socially optimal.

The foreign antidumping laws and the U.S. antitrust laws must provide a substantial inhibition to U.S. firms, especially to price discrimination. Managers of large U.S. firms defer to their general counsels on such matters, and the general counsels will generally counsel against price discrimination. The result is Rangan and Lawrence's pricing strategy, under which a firm charges the same price to its own affiliates and allows the affiliates to charge the appropriate prices in foreign markets.

In conclusion, let me draw your attention again to figure 2 , which is a fascinating but extremely troubling figure. According to the economic theory taught by teachers of open economies, the little squares should all be along the zero line. Yet manifestly they are not. Lumber and furniture is up above 35 percent, paper and allied products are over 15 percent, and so forth.

What is going on? Does this reflect aggregation bias? If so, Rangan and Lawrence should redo their study at a lower level of aggregation. It is very likely that some of the observations do reflect aggregation bias. For example, in lumber and furniture, my guess is that most of the exports are lumber, and much of the domestic sales is furniture. Perhaps there is also significant aggregation bias in paper and allied products as well.

To the extent that the results in figure 2 do not reflect aggregation bias, they suggest that commodity arbitrage is more difficult in the short run than economists typically assume. The short run here-keep in mind-is three to four years, the timeframe that is relevant for business cycle analysis.

In open economy macroeconomics, one of the unquestioned premises is the law of one price, such that the same commodity-after allowing for transfer costs-sells at the same price in all markets when converted at the prevailing exchange rate. Figure 2 brings into serious 
question the law of one price. To the extent that it is not aggregation bias that is showing up here, but rather the difficulties, for many legal and practical reasons, of international arbitrage, these findings suggest that we have to review one of the basic premises of macroeconomic analysis.

\section{General Discussion}

Several panel members focused on differences between the behavior of U.S. and foreign firms. Robert Hall reported Michael Knetter's findings on German and Japanese auto makers. Even though Knetter's price data reflected intrafirm transactions-like the data in the RanganLawrence paper-Knetter found that these firms priced to market, unlike the evidence for the transportation industry in figure 2 of the paper. Martin Baily suggested that large Japanese firms may be able to price to market more easily than U.S. firms because large Japanese firms have a sizable productivity advantage over other firms in their industry, and can therefore absorb rises in the exchange rate and still make a profit. Baily also suggested that smaller firms are often subsidiary to large Japanese firms and in competition with foreign suppliers, so that the large firms can often extract price concessions from them when the exchange rate rises. Greg Mankiw asked whether the use of the dollar as a unit of account for purchases of intermediate inputs could provide an explanation for differences in pricing behavior. Rangan replied that this denomination effect is unlikely to distinguish U.S. multinationals from foreign exporters. In particular, foreign costs account for 80 percent of the value added of sales by foreign affiliates of U.S. multinationals, so that these affiliates would be subject to the same denomination effect that Mankiw described.

The panel also focused on the data problems that Rangan and Lawrence described. Peter Hooper noted that a puzzle emerges if the export price data erroneously fail to reflect pricing-to-market behavior by U.S. exporters for the reasons Rangan and Lawrence suggest. This measurement error implies that the variability of the BLS export price data (measured in foreign currencies) is artificially inflated by fluctuations in exchange rates, leading to an underestimation of the elasticity of demand for U.S. exports. But this elasticity is generally estimated to be about the same as the elasticity of demand for U.S. imports. So if Ran- 
gan and Lawrence are correct about measurement error in the export data, U.S. exports, in fact, could be significantly more price-elastic than U.S. imports. This is a puzzle because there is no particular reason, $a$ priori, to believe the price elasticity of exports exceeds that of imports. Lawrence replied that the export price data are not subject to classical measurement error, but rather that the published export prices are picking up the prices relevant for sourcing decisions rather than the prices relevant to the decisions of final consumers. Thought of in these terms, Lawrence saw no puzzle in the estimated price elasticities.

Some members of the panel asked to what extent the data on U.S. imports are subject to the same biases as the export price data. Rangan replied that this is not likely to be the case for two reasons. First, the BLS collects its data on import prices from U.S. importers, not foreign exporters. Second, there is evidence that intrafirm trade is notably less significant for foreign firms than for U.S. firms.

Andrei Shleifer asked what theoretical basis existed for the premise that prices charged to foreign affiliates should not change when the exchange rate changes. Lawrence responded that a multinational parent selling to its foreign subsidiary would just use the U.S. cost as its price in order to provide subsidiaries with accurate cost information for sourcing decisions. Finally, Peter Hooper noted a testable implication of the idea that exchange rates were important in sourcing decisions. If they were important, then exchange rate movements should cause fluctuations in the market share and profits of U.S. resident firms. 


\section{References}

Alterman, William. 1991. "Price Trends in U.S. Trade: New Data, New Insights." In International Economic Transactions: Issues in Measurement and Empirical Research, edited by Peter Hooper and J. David Richardson. Chicago: University of Chicago Press.

$\rightarrow$ Baldwin, Richard. 1988. "Hysteresis in Import Prices: The Beachhead Effect." American Economic Review 78(4):773-85.

Benke, Jr., Ralph L., and James Don Edwards. 1980. Transfer Pricing: Techniques and Uses. New York: National Association of Accountants.

Bergsten, C. Fred, Thomas Horst, and Theodore H. Moran. 1978. American Multinationals and American Interests. Washington: Brookings.

$\rightarrow$ Cho, Kang Rae. 1990. "The Role Product-Specific Factors in Intra-Firm Trade of U.S. Manufacturing Multinational Corporations." Journal of International Business Studies 21(2):319-30.

Diewert, W. Erwin. 1985. "Transfer Pricing and Economic Efficiency." In Multinationals and Transfer Pricing, edited by Alan M. Rugman and Lorraine Eden. New York: St. Martin's Press.

$\rightarrow$ Dixit, Avinash K. 1989. "Hysteresis, Import Penetration, and Exchange Rate Pass-Through." Quarterly Journal of Economics 104(2):205-28.

$\rightarrow$ Domowitz, Ian, R. Glenn Hubbard, and Bruce C. Petersen. 1987. "Oligopoly Supergames: Some Empirical Evidence on Prices and Margins." Journal of Industrial Economics 35(4):379-98.

$\longrightarrow \rightarrow$. 1988. "Market Structure and Cyclical Fluctuations in U.S. Manufacturing." Review of Economics and Statistics 70(1):55-66.

$\rightarrow$ Dornbusch, Rudiger. 1987. "Exchange Rates and Prices." American Economic Review 77(1):93-106.

Eden, Lorraine. 1985. "The Microeconomics of Transfer Pricing." In Multinationals and Transfer Pricing, edited by Alan M. Rugman and Lorraine Eden. New York: St. Martin's Press.

- and Maureen Appel Molot. 1992. "The NAFTA Autos Provisions: The Next Stage of Managed Trade." Paper prepared for the North American Free Trade Symposium, C.D. Howe Institute, Toronto (December 5-6, 1992).

Encarnation, Dennis J. 1992. Rivals beyond Trade: America versus Japan in Global Competition. Ithaca: Cornell University Press.

Feenstra, Robert C. 1989. "Symmetric Pass-Through of Tariffs and Exchange Rates Under Imperfect Competition: An Empirical Test." Journal of International Economics 27(1-2):24-45.

$\rightarrow$ Froot, Kenneth A., and Paul D. Klemperer. 1989. "Exchange Rate PassThrough when Market Share Matters." American Economic Review 79(4):637-54.

$\rightarrow$ Goldsbrough, David. J. 1981. "International Trade of Multinational Corporations and Its Responsiveness to Changes in Aggregate Demand and Relative Prices." International Monetary Fund Staff Papers 28(3):573-99. 
Helleiner, Gerald K. 1981. Intra-firm Trade and the Developing Countries. New York: St. Martin's Press.

$\rightarrow$ Hirshleifer, Jack. 1956. "On the Economics of Transfer Pricing." Journal of Business 29:172-84.

Hooper, Peter, and Catherine L. Mann. 1989. "Exchange Rate Pass-Through in the 1980s: The Case of U.S. Imports of Manufactures." BPEA, 1:1989, 297-329.

$\rightarrow$ Horst, Thomas. 1971. "The Theory of the Multinational Firm: Optional Behavior Under Differing Tariff and Tax Rates." Journal of Political Economy 79(5):1059-72.

Hufbauer, Gary Clyde, and Jeffrey J. Schott. 1993. NAFTA: An Assessment. Washington: Institute for International Economics.

Junz, H. B., and R. R. Rhomberg. 1965. "Prices and Export Performance of Industrial Countries 1953-63.” IMF Staff Papers, vol. XII (July).

Kasa, Kenneth. 1992. "Adjustment Costs and Pricing-to-Market: Theory and Evidence." Journal of International Economics 32(1-2):1-30.

$\rightarrow$ Knetter, Michael M. 1989. "Price Discrimination by U.S. and German Exporters." American Economic Review 79(1):198-210.

1992. "Multinationals and Pricing to Market Behavior." In Multinationals in the New Europe and Global Trade, edited by Michael W. Klein and Paul J. J. Welfens. Berlin: Springer-Verlag.

$\rightarrow \cdot$. 1993. "International Comparisons of Pricing-To-Market Behavior." American Economic Review 83(3):473-86.

Kravis, Irving B., and Robert E. Lipsey. 1971. Price Competitiveness in World Trade. New York: National Bureau of Economic Research.

Krugman, Paul R. 1987. "Pricing To Market When the Exchange Rate Changes." In Real-Financial Linkages Among Open Economies, edited by Sven W. Arndt and J. David Richardson. Cambridge, Mass.: MIT Press.

- 1991. Has the Adjustment Process Worked? Washington: Institute for International Economics.

—, and Richard E. Baldwin. 1987. "The Persistence of the U.S. Trade Deficit." BPEA, 1:1987, 1-43.

Lawrence, Robert Z. 1990a. "U.S. Current Account Adjustment: An Appraisal." BPEA, 2:1990, 343-82.

- 1990b. "American Manufacturing in the 1990s: The Adjustment Challenge." In American Manufacturing in a Global Market, edited by Kenneth W. Chilton, Melinda E. Warren, and Murry L. Weidenbaum. Boston: Kluwer Academic Publishers.

Lipsey, Robert E. 1993. "The Data Infrastructure for International Economic Research: A Selective Survey." Unpublished paper. CUNY, Queens College (April 2).

— , and Irving B. Kravis. 1986. "The Competitiveness and Comparative Advantage of U.S. Multinationals, 1957-83.” Working Paper 2051. Cambridge, Mass.: National Bureau of Economic Research (October). 
Linda Molinari, and Irving B. Kravis. 1991. "Measures of Prices and Price Competitiveness in International Trade in Manufactured Goods." In International Economic Transactions: Issues in Measurement and Empirical Research, edited by Peter Hooper and J. David Richardson. Chicago: University of Chicago Press.

Little, Jane Sneddon. 1986. "Intra-Firm Trade and U.S. Protectionism: Thoughts Based on a Small Survey." New England Economic Review (Jan./ Feb.):42-51.

- 1987. "Intra-Firm Trade: An Update." New England Economic Review (May/June):46-51.

Maddala, G. S. 1992. Introduction to Econometrics. New York: Macmillan.

Marston, Richard C. 1990. "Pricing to Market in Japanese Manufacturing." Journal of International Economics 29(3-4):217-36.

- 1991. "Price Behavior in Japanese and U.S. Manufacturing." In Trade with Japan: Has the Door Opened Wider? edited by Paul R. Krugman. Chicago: University of Chicago Press.

Moffett, Michael H., 1989. "The J-Curve Revisited: An Empirical Examination for the United States." Journal of International Money and Finance $8(3): 425-44$.

$\rightarrow$ Ohno, Kenichi. 1990. "Exchange Rate Fluctuations, Pass-Through, and Market Share." International Monetary Fund Staff Papers 37(2):294-310.

Organisation for Economic Co-operation and Development. Various issues. Indicators of Industrial Activity: 1992/2. Paris: OECD

Prahalad, C. K., and Yves L. Doz. 1987. The Multinational Mission: Balancing Local Demands and Global Vision. New York: Free Press.

Rangan, Subramanian. Forthcoming. "U.S. Corporate Pricing and Sourcing Responses to Exchange Rate Fluctuations: Are They Really Different?" Ph.D. diss., Harvard University.

Rugman, Alan M., and Lorraine Eden, eds. 1985. Multinationals and Transfer Pricing. New York: St. Martin's Press.

Stern, Robert M., Jonathan Francis, and Bruce Schumacher. 1976. Price Elasticities in International Trade: An Annotated Bibliography. London: Macmillan.

United Nations. 1991. Statistical Yearbook for Asia and the Pacific.

U.S. Bureau of Census and U.S. Bureau of Labor Statistics. Various years. Trade and Employment,Third Quarter. Washington: Department of Commerce and Department of Labor.

U.S. Bureau of Economic Analysis. Various years. U.S. Direct Investment Abroad: Operations of U.S. Parent Companies and Their Affiliates. Washington: Department of Commerce.

Waterson, Michael. 1984. Economic Theory of the Industry. Cambridge: Cambridge University Press. 